\title{
Bovine Dermatophytosis Caused by Trychophyton Verrucosum: A Case Report
}

\author{
E S Swai* and P N Sanka \\ Veterinary Investigation Centre \\ Arusha, Tanzania \\ * Corresponding author email: ESswai@gmail.com \\ Received: 11-10-2011, Accepted: 06-11-2011, Published Online: 19-01-2012 \\ doi: 10.5455/vetworld.2012.297-300
}

\begin{abstract}
Outbreak of acute bovine dermatophytosis in a large scale dairy herd in Arusha region of Tanzania is described. Clinical history of the condition complimented with detailed examination of the affected animals $(33.3 \%, 14 / 42)$ revealed that animals were pastured during the day and padlocked at night. The main clinical signs presented were gray-white, discrete, crusty, circumscribed extensive lesion all over the body. Skin scrapings were taken from the lesions for mites and fungal isolation and characterization. Pinched off lesion were examined in $30 \% \mathrm{KOH}$ preparations and scrapping were directly streaked on Trichophyton Agar and incubated at $37{ }^{\circ} \mathrm{C}$. Bacteriological and fungal stain of the colonies revealed positive mycotic structures spherical, pyriform to calvate often of irregular shape which is characteristic of Trychophyton verrucosum. The isolation and morphological identification of T. verrucosum supported the clinical diagnosis. Considering the large number of animals involved, and the severity of the lesions, that necessitated veterinary intervention, it would be necessary to asses the prevalence and economic importance of the disease in dairy herd establishments in Tanzania.

Key words: Arusha, Cattle, Tanzania, T. verrucosum
\end{abstract}

To cite this article :

Swai ES and Sanka PN (2012) Bovine Dermatophytosis Caused by Trychophyton Verrucosum: A Case Report, Vet. World. 5(5): 297-300, doi: 10.5455/vetworld.2012.297-300

\section{Introduction}

Dermatophytosis, caused by Trichophyton verrucosum, is a disease that affects many spp of livestock and occurs as an acute or chronic skin disease (Svejgaard, 1986; Chermette et al., 2008). Close confinement, host factors (age, immunocompetence, type of breed, host grooming behavior), dietary factors deficiencies, condition of exposed skin surfaces and production system accompanied by prolonged wetting are thought to be important predisposing factors (Moretti et al., 1998; Papini et al., 2009). Affected animals initially develop characteristically discrete, scaling patches of hair loss with greywhite crust that later become thickly suppurated crust whose location is highly variable (Radostits et al., 2000).

In tropical and sub-tropical areas, the disease can be epizootic and can result in considerable economic losses as a result of lost production, public health concern, premature culling, treatment costs and down grading of hides and skins (Pandey and Cabaret, 1980; Ogbonna et al., 1986; Wabacha et al., 1998; Nweze, 2010). Although the clinical disease has been recognized in several African countries (Pandey, 1979; Abou-Gabal et al., 1976; Efuntoye and Fashanu, 2002) the occurrence of clinical disease in Tanzania has never been reported previously and, therefore, not fully thoroughly known. This case report describes an outbreak of acute bovine dermatophytosis in a large scale dairy herd and highlights that the disease in Tanzania could occur in outbreak proportions and in clinically severe form as has been reported in other countries in west and north Africa. We believe that this is the first documented outbreak of a severe form of bovine cuteneous dermatophytosis in exotic dairy animal in Tanzania.

\section{Case history}

On 24 November 2006, the manager of a large scale Aryshire breed dairy farm with 42 heads of cattle reported to Veterinary Investigation Centre (VIC), Arusha, the occurrence of skin lesions in a number of animals. At the farm, a clinical history of the condition was taken and this was followed by a clinical examination of the affected animals. The examination revealed that affected animals, mainly adults were 
pastured during the day and padlocked at night. The main clinical signs presented were gray-white, crusty, extensive lesion all over the body. Two weeks later, 7 out of 42 animals (all sex) were noted to have similar lesions. A total of 14 (33.3\%) cases were observed during the outbreak that lasted from mid November 2006 when the weather was hot and dry. The mean monthly temperatures were $33{ }^{\circ} \mathrm{C}$ and $32{ }^{\circ} \mathrm{C}$ for Nov, Dec 2006 and $32^{\circ} \mathrm{C}$ for Jan 2007.

\section{Materials and Methods}

Outbreak area: Outbreak was reported at a large scale (defined by the dairy development authority as farms having more than 10 graded or pure exotic dairy breed of all age and sex) institute farm located in Arusha Municipality, Tanzania. Geographically, the municipality is situated at the foot of Mount Meru (Lat 03'16-03'20S and Longt 36'37-36'50E) and intersect the great north Road from Cape Town to Cairo. The annual average rainfall is $800-1200 \mathrm{~mm}$ and are normally concentrated in two season; from the end of March to May (long rains) and from the end of October to December (short rains). Mean temperature ranges from $15^{\circ} \mathrm{C}$ to $30^{\circ} \mathrm{C}$ and the human population is estimated to be 516,000 growing at a rate of $4 \%$ per annum (URT, 2002).

Animal and management system: Investigated animals comprised crosses of Bos taurus cattle (mainly Ayrshire) with the Bos indicus breed, the indigenous Tanzania short horn zebu (TSHZ). The level of taurine blood genes inheritance varied from $62.5 \%$ to equal or above $75 \%$. Animals were pastured during the day and padlocked at night. Cattle are vaccinated yearly against Anthrax, Hemorrhagic Septicemia, Lumpy Skin Disease and s.19 brucella vaccine for female calves $<10$ months old. Control of ectoparasites mainly ticks, twice very four weeks is done by using Decatix ${ }^{\circledR}(2.5 \% \mathrm{~m} / \mathrm{v}$, Deltamethrin, Coopers, Zimbabwe). Anthelmintic treatment using albendazole (Valbazen, Pfizer Animal Health, 10mg $/ \mathrm{kg}$ body weight) is generally limited to calves.

Sampling and mycological examination: Using sterile surgical blade, skin scrapings were taken from the lesions for mite and fungal isolation and characterization. Laboratory handling, storage and examination of clinical specimens for mites and fungi were undertaken at VIC laboratory in Arusha. Pinched off lesion were examined in $30 \% \mathrm{KOH}$ preparations and proceeding of the skin scrapping were directly streaked on Trichophyton Agar (Difco: Cat.No 287710) and incubated at $37^{\circ} \mathrm{C}$.

\section{Results}

Clinical assessment of the lesions: Two types of skin lesions were observed in the affected animals. The most common lesions were manifested as discrete, circumscribed lesion of variables sizes that were covered with grey-white crust. Some crusts had coalesced to form large lesions covering large areas of the skin. The pustular lesions were less common and involved the formation of small scabs protruding above the skin surface causing the hair over the affected site to be erect and matted in tufts. Removal of the crusts from the discrete circumscribed lesions revealed an alopecic, red, moist keratinized tissue. The lesions of the pustular form were evenly distributed over the whole skin surface while for the crust form; the lesions were mainly on the lateral neck, muzzle, head region, brisket and down the hind limbs. A tentative diagnosis of cutaneous bovine dermatophytosis was made on 25 Nov 2006 and the affected animals were isolated from the rest of the animals.

Laboratory analysis of the samples: Direct microscopic examination of epidermal scales, using $30 \% \mathrm{KOH}$, were negative for mites, but showed hyaline-septated arthroconidiate hyphae suggesting dermatophyte infection. Culture growth was relatively slow, forming glabrous, heaped, white to grey raised granular colonies in $72 \mathrm{hrs}$ which were adherent to the medium. Microscopic examination of the colonies revealed positive mycotic structures spherical, pyriform to calvate often of irregular shape which is characteristic of Trychophyton spp (Takatori et al., 1993).

\section{Discussion}

Trichophyton verrucosum is a cosmopolitan zoophilic species of fungi that causes ringworm in cattle and other farm animals, from which human can become infected (Weber, 2000). Infected human may experience a strong inflammatory infection which may typically occur in the scalp, the beard region, or the glabrous skin (Nweze, 2010). The significance of this investigation is that persistent infections of farm animals by fungal like $T$. verrucosum in addition to its deleterious effects on cattle causes public health hazards (Nweze, 2010). Several outbreaks of this disease in animals have been reported in which spread to humans is not uncommon, eg., 20 cattle were infected and 2 animal attendants acquired the disease in Kenya (Wabacha et al., 1998); in China twelve cases were seen in farm animal attendants (Ming et al., 2006). Our study is the first to report evidence of a 
dermatophytosis due to $T$. verrucosum in cattle in Tanzania. Some of the cattle examined had few papules, together with hard, dry, crusty lesions which were confined to certain areas of the body particularly the muzzle, flank and the back. In some few cases, the lesions were generalized and covered the whole body especially the back, neck, perinneal region, lower limb, tail and ears of the affected animals. The clinical signs observed in the present outbreak were similar to those reported for dermatophytosis in cattle (Chermette et al., 2008). The back and flank lesions occurred more frequently than on the other parts of the body. The two sites are more exposed than the other parts of the body and as a result they are more subjected to excessive contact, wetness and maceration by rain water. It's also conceived that these parts of the body would be more vulnerable to contact and injuries and therefore predisposing the back and flank to infection by $T$. verrucosum.

The isolation and morphological identification of T. verrucosum supported the clinical diagnosis. In the present outbreak, the crust were grey-white, greasy and firmly attached to hair fibres and when removed they left a red, (keratinized tissue) moist epidermis oozing serum or blood. These findings were consistent with dermatophytosis lesions as described in the literature (Rebell and Taplin, 1970; Rippon, 1988). The treatments of animals with broad-spectrum acting Ivermectin $1 \%$ ( Inouko generics, 96 rue de Victoire 75009 , Paris, France) at a dose rate of $200 \mathrm{mcg} / 50 \mathrm{~kg}$ body weight subcutaneously repeated every three weeks in combination with long acting antibiotics Oxtetracycline (Ox vet 20\%, Hebei New Century Pharmaceutical Co., Ltd, China) at a dose rate of $10 \mathrm{mg} / \mathrm{kg}$ body weight every 2 days for 10 days was not able to cure the animals. Other medication that were tried, however, with no curative results were topically application of Miconazole ointments $2 \%$ Micatin (Daktacort in UK) applied twice daily for three weeks. Similarly animals were treated orally with Griseofulvin (Gris-PEG, Lembet Vet Supply) at a dosage rate of $10 \mathrm{mg} / \mathrm{kg}$ body weight for 6 weeks and washing skin lesion and housing premises with disfenctants (sprayed three times per week) mainly chlorhexidine (Sirmaxo Chemicals PVT, Mumbai, India). Affected animal were culled. In this survey, no attempt was made to undertake detailed investigations such as antifungal susceptibility tests and genotyping analysis, to determine potential candidate antifungal drug and strain of Trichophyton present in the outbreak area. Resources constraints affecting logistics and laboratory capacity were the main reason.

Considering the large number of animals involved, and the severity of the lesions, that necessitated veterinary intervention, it would be necessary to asses the prevalence and economic importance of the disease in dairy herd establishments in Tanzania.

\section{Acknowledgements}

We acknowledge the cooperation and commitment of the farm Manager and his stockmen during the investigation. This investigation was financially supported by MOLD\&F surveillance funds.

\section{References}

1. Abou-Gabal, M.; El-Galil, G. A.; El-Nor, E.A., El-Rehim D. A. (1976). Animal ringworm in upper Egypt. Sabouraudia, 14(1):33-36.

2. Chermette, R.; Ferreiro, L., Guillot, J. (2008). Dermatophytoses in animals. Mycopathologia, 166(5-6):385-405.

3. Efuntoye, M. O., Fashanu, S. O. (2002). Fungi isolated from skins and pens of healthy animals in Nigeria. Mycopathologia, 153(1): 21-32.

4. Moretti, A.; Boncio, L.; Pasquali, P., Fioretti, D. P. (1998). Epidemiological aspects of dermatophyte infections in horses and cattle. Zentralbl Veterinarmed B, 45(4): 205-208.

5. Ming, P. X.; Ti, Y. L. X., Bulmer, G. S. (2006). Outbreak of Trichophyton verrucosum in China transmitted from cows to humans. Mycopathologia, 161:225-228.

6. Nweze, E.1. (2010). Dermatophytosis among children of Fulani/Hausa herdsmen living in isolated camps in southeastern Nigeria. Rev Iberoam Micol, 27(4):191-194.

7. Ogbonna, C. I.; Enweani, I. B., Ogueri, S. C. (1986). The distribution of ringworm infections amongst Nigerian nomadic Fulani herdsmen. Mycopathologia, 96(1): 45-51.

8. Pandey, V. S. (1979). Some observations on Trichophyton verrucosum infection in cattle in Morocco. Ann Soc Belg Med Trop, 59(2):12731.

9. Pandey, V. S. and Cabaret, J. (1980). The distribution of ringworm lesions in cattle naturally infected by Trichophyton verrucosum. Ann Rech Vet, 11(2):179-84.

10. Papini, R.; Nardoni, S.; Fanelli, A., Mancianti, F. (2009). High infection rate of Trichophyton verrucosum in calves from Central Italy. Zoonoses Public Health, 56(2):59-64.

11. Radostits, O. M.; Gay, C. C.; Blood, C. D., Hinchcliff, K.W. (2000). Veterinary Medicine, 
a text book of the diseases of cattle, sheep, pigs, goats and horses. $9^{\text {th }}$ edition, New York: W.B. Sounders Company Ltd. 960.

12. Rebell, G. and Taplin, D. (1970). The Dermatophytes $2^{\text {nd }}$. revised edition. University of Miami Press, Coral Gables, Florida. USA.

13. Rippon, J. W. (1988). Medical Mycology. $3^{\text {rd }}$ Edition. W. B.Saunders CO., Philadelphia,USA.

14. Svejgaard, E. (1986). Epidemiology and clinical features of dermatomycoses and dermatophytoses. Acta Derm Venereol Suppl (Stockh), 121:19-26.

15. Takatori, K.; Takahashi, A.; Kawai, S.; Ichijo, S. and Hasegawa, A. (1993). Isolation of Trichophyton verrucosum from lesional and non-lesional skin in calves. $J$ Vet $\mathrm{Med} S \mathrm{Sci}$, 55(2):343-344.

16. URT (United Republic of Tanzania) (2002). Population and household census. Available at: http: // www.tanzania.go.tz/cencus/table5. htm. 2002; Accessed November, 2011.

17. Wabacha, J. K.; Gitau, G. K.; Bebora, L. C.; Bwanga, C. O.; Wamuri, Z. M. and Mbithi, P. M.(1998). Occurrence of dermatomycosis (ringworm) due to Trichophyton verrucosum in dairy calves and its spread to animal attendants. JSAfr Vet Assoc, 69(4):172-173.

18. Weber, A. (2000). Mycozoonoses with special regard to ringworm of cattle. Mycoses, 43: 2022.

$$
* * * * * * * *
$$

